\title{
THE EFFECTS OF FOLIAR NUTRITION WITH InCa FERTILIZER ON THE CHEMICAL COMPOSITION OF LEAVES AND FRUITS OF SWEET CHERRY
}

\author{
Grzegorz Mikiciuk', Małgorzata Mikiciuk², Ewa Możdżer³, \\ Małgorzata Statkiewicz' ${ }^{1}$ Urszula Chylewska'
}

1 Department of Horticulture, Faculty of Environmental Management and Agriculture, West Pomeranian University of Technology in Szczecin, Słowackiego 17 Str., 71-434 Szczecin, Poland, e-mail: grzegorz.mikiciuk@ zut.edu.pl

2 Department of Plant Physiology and Biochemistry, Faculty of Environmental Management and Agriculture, West Pomeranian University of Technology in Szczecin, Słowackiego 17 Str., 71-434 Szczecin, Poland,, e-mail: malgorzata.mikiciuk@zut.edu.pl

3 Department of Soil Science, Grassland Management and Environmental Chemistry Faculty of Environmental Management and Agriculture, Western Pomeranian University of Technology in Szczecin, Słowackiego 17 Str., 71-434 Szczecin, Poland, e-mail: ewa.mozdzer @zut.edu.pl

Received: 2014.11.12

Accepted: 2015.02 .04 Published: 2015.04.01

\begin{abstract}
The aim of this study was to evaluate the effect of the foliar fertilizer InCa on the chemical composition of fruits and leaves of sweet cherry cultivar 'Burlat'. The study involved 14-year old sweet cherry trees of 'Burlat' cultivar, grafted onto 'PHL-A' rootstock and growing at $4 \times 3 \mathrm{~m}$ spacing. The trees were sprayed with InCa calcium fertilizer based on CaT technology (manufacturer: Plant Impact). The fertilizer was applied three times, at a dose of $1.5 \mathrm{dm}^{3} \cdot$ ha. The first foliar fertilization was performed at the beginning of the flowering period, and the next two took place at fourteen-day intervals. The fruits were analysed for nitrate content, and both fruits and leaves were considered for dry weight and macro- and micronutrient analysis. The use of InCa fertilizer improved the dry matter and calcium content and reduced potassium, magnesium and cadmium level in the leaves and fruits of sweet cherry. The fertilizer facilitated narrowing $\mathrm{K}: \mathrm{Ca}$ and $\mathrm{K}:(\mathrm{Ca}+\mathrm{Mg})$ ratioes and extending of $\mathrm{K}: \mathrm{Mg}$, and especially $\mathrm{Ca}: \mathrm{Mg}$ ratio in both leaves and fruits. Foliar supplementation with the investigated preparation resulted in an increase in nitrogen and manganese content, and a drop in phosphorus, copper, nickel and lead concentration in the leaves of the studied sweet cherry cultivar.
\end{abstract}

Keywords: sweet cherry, InCa fertilizer, macroelements, microelements.

\section{INTRODUCTION}

Appropriate calcium nutrition is one of the most important factors affecting the quality of fruit yield, especially of sweet cherries and apples. In sweet cherry, calcium reduces the adverse effect of fruit cracking [Fernandez and Flore, 1998, Sitarek and Grzyb 1999, Chełpiński et al. 2007], and in apples it reduces the risk of physiological disorders and improves storability [Andziak et al. 2004, Tomala and Soska 2004]. Foliar nutrition is a common approach ensuring adequate amounts of calcium in the fruit. To optimize calcium nutrition, foliar fertilizers are very often used, and they not only provide the plants with calcium, but also activate its uptake. One of commercial fertilizers of this type is a preparation called InCa. InCa fertilizer (manufactured by Plant Impact), based on CaT technology, is designed to activate a calcium-auxin pump and calcium channels to improve calcium supply levels [Arysta LifeScience, 2013].

The aim of this study was to evaluate the effect of the foliar fertilizer InCa on the chemical composition of fruits and leaves of sweet cherry cultivar 'Burlat'. 


\section{MATERIAL AND RESEARCH METHODS}

The study, conducted in the years 2011-2013, was designed as a univariate experiment involving randomized blocks with five replicates. The study involved 14-year old sweet cherry trees of 'Burlat' cultivar, grafted onto 'PHL-A' rootstock and growing at $4 \times 3 \mathrm{~m}$ spacing. The trees were sprayed with InCa calcium fertilizer based on CaT technology (manufacturer: Plant Impact), containing $8.0 \% \mathrm{~N}, 13.0 \% \mathrm{CaO}$, and $1.0 \% \mathrm{Zn}$ [Arysta LifeScience, 2013]. The fertilizer was applied three times, at a dose of $1.5 \mathrm{dm}^{3} \cdot h$ h. The first foliar fertilization was performed at the beginning of the flowering period, and the next two took place at fourteen-day intervals. Control trees were sprayed with distilled water. The fruits were analysed for nitrate content, and both fruits and leaves were considered for dry weight and macro- and micronutrient analysis. Dry matter was determined according to PN-75C-04616/01, and nitrates as per PN-R-04030. Nitrogen content was determined with the Kjeldahl method PN ISO 13878, phosphorus by the colorimetric method according to Barton, and sulfur by nephelometry on Perkin Elmer device Lambda EZ 150. The amount of potassium and calcium were determined by flame photometry, and magnesium, cadmium, copper, manganese, nickel, lead and zinc by atomic absorption spectrometry on a Perkin Elmer spectrometer AAS 300. A stock solution for the determination of the total content of the analyzed elements was obtained by wet mineralization of the plant material according to the Polish standards PN-ISO 11466 and PN-ISO 11047.

The resulting figures were subjected to oneway analysis of variance, in a random block arrangement. To determine the significance of differences between means, Duncan's confidence half intervals, at the significance level $\alpha=0.05$, were calculated.

\section{RESULTS AND DISCUSSION}

The applied calcium fertilizer increased the dry matter content in the leaves and fruits of the studied sweet cherry cultivar (Figure 1). Bieniek et al. [2011] reported that the dry matter content in the fruits of sweet cherry 'Burlat' cv. ranged from $13.6 \%$ to $19.0 \%$, and the average was $15.8 \%$. In this study, the dry matter content in fruits ranged from $12.6 \%$ (control) to $14.4 \%$ (fruit supplemented with InCa fertilizer).

Calcium fertilization resulted in higher concentration of nitrogen and reduction in phosphorus content in the sweet cherry leaves. Despite a drop in phosphorus content triggered by $\mathrm{InCa}$ treatment, its concentration in both control and fertilized leaves seems to be optimal [Meszka et al. 2013]. Calcium supplementation did not affect nitrogen and phosphorus level in fruits (Table 1). Similar findings were published by Lanauskas et al. [2012], who found no effect of foliar nutrition of nitrogen content in the apples of 'Ligol' cultivar.

InCa spraying proved to be an effective way to deliver calcium to the plants, as it increased its content in both the leaves and the fruits. Leaf

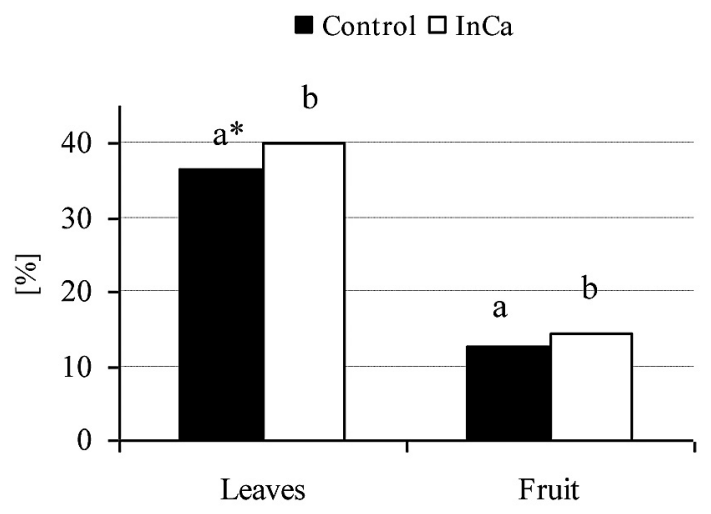

Figure 1. Influence of InCa fertilizer on content of dry matter in leaves and fruit of sweet cherry cv. 'Burlat'. * Means assigned identical letters do not differ significantly at the level of significance $\alpha=0,05$

Table 1. Influence of InCa fertilizer on content of macroelements and sodium in leaves and fruit of sweet cherry cv. 'Burlat'

\begin{tabular}{|c|c|c|c|c|c|c|}
\hline \multirow{2}{*}{ Specification } & $\mathrm{N}$ & $P$ & $\mathrm{~K}$ & $\mathrm{Ca}$ & $\mathrm{Mg}$ & $S$ \\
\hline & \multicolumn{6}{|c|}{$\mathrm{g} \cdot \mathrm{kg}^{-1}$ dry matter } \\
\hline \multicolumn{7}{|c|}{ Leaves } \\
\hline Control & $31,5 \mathrm{a}$ & $3,66 \mathrm{~b}$ & $16,2 b$ & $19,1 \mathrm{a}$ & $4,87 \mathrm{~b}$ & $0,88 a$ \\
\hline $\operatorname{lnCa}$ & $35,4 \mathrm{~b}$ & $3,36 \mathrm{a}$ & 14,9 a & $24,6 b$ & $4,01 \mathrm{a}$ & $0,88 a$ \\
\hline \multicolumn{7}{|c|}{ Fruit } \\
\hline Control & 9,27 a & 3,16 a & $11,20 \mathrm{a}$ & 2,14 a & $1,47 \mathrm{~b}$ & $0,02 \mathrm{a}$ \\
\hline $\mathrm{InCa}$ & $10,87 a$ & 3,19 a & $9,51 \mathrm{a}$ & $3,60 \mathrm{~b}$ & $1,16 \mathrm{a}$ & $0,02 a$ \\
\hline
\end{tabular}

* Means assigned identical letters do not differ significantly at the level of significance $\alpha=0,05$. 
calcium concentration rose by $28.8 \%$, and in the fruits it was by $68.2 \%$ higher than in control (Table 1). According to Tomala and Soska [2004], foliar nutrition with calcium containing fertilizers improved calcium concentration in apples. Fertilization led to lowering potassium and magnesium level. Potassium content in the leaves and fruits was by $8.0 \%$ and $15.1 \%$ lower, and for magnesium, it was reduced by $17.7 \%$ and $21.1 \%$. (Table 1). Changes were also detected in ion ratio in the leaves and fruits (Figures 3 and 4). The use of InCa fertilizer resulted in narrowing of $\mathrm{K}: \mathrm{Ca}$ and $\mathrm{K}:(\mathrm{Ca}+\mathrm{Mg})$ ratio. Foliar nutrition contributed to the expansion of $\mathrm{K}: \mathrm{Mg}$ and especially $\mathrm{Ca}: \mathrm{Mg}$ ratio, both in the leaves and fruits. The relationship between plant calcium and potassium content has been discussed by many authors. Andziak et al. [2004] indicated that in apples an increase in potassium concentration was associated with a decrease in calcium content. The content of potassium and magnesium found in the leaves of the studied cultivar seems to be optimal, regardless of the experimental variant [Meszka et al. 2013]. The obtained results are corroborated by the literature data, as according to Wójcik [2004], foliar calcium supplementation is an effective way of increasing the content of this component in fruits. The author claims also that this approach should be recommended in the integrated fruit production, because the application method is environmentally friendly and it improves plant productivity and fruit quality.

The preparation affected neither the content of sulfur in the leaves and fruits (Table 1), nor the accumulation of nitrates in the fruits of the studied sweet cherry cultivar (Figure 2).

Foliar fertilization with InCa had no effect on the amount of zinc in the leaves and the content of manganese, copper, nickel or lead in the fruits (Table 2). The fertilizer caused a rise in manganese level and a reduction in the accumulation of copper, nickel and lead in the leaves of 'Burlat' sweet cherry (Table 2). Increased content of manganese in the leaves of apple trees fertilized with calcium chloride was also reported by Khalifa et al. [2009]. The amount of this element in the leaves of the studied cultivar was lower than that reported in the literature for the 'Bing' and 'Sunburst' cultivars [Neilsen and Kappel, 1996, Jiménez et al. 2004]. Zinc content in the leaves was similar to the levels in 'Bing' cultivar [Neilsen and Kappel 1996], and copper content was comparable to the amount of copper accumulated by the leaves of
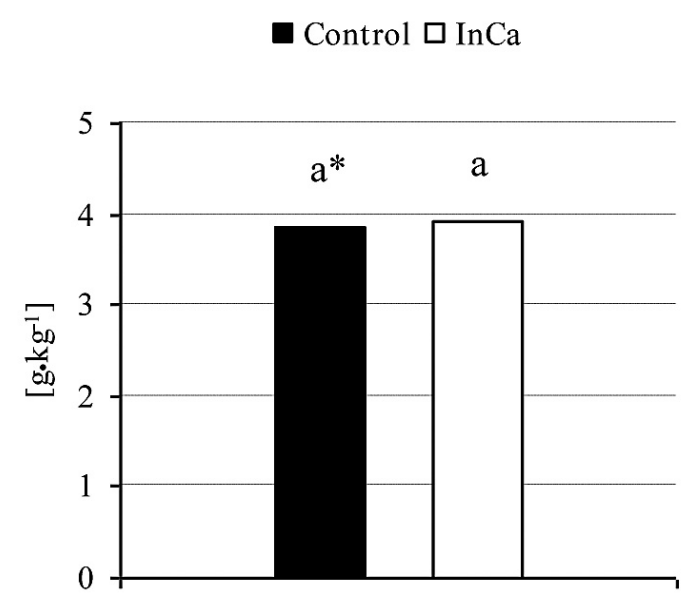

Figure 2. Influence of InCa fertilizer on content of nitrates in fruit of sweet cherry cv. 'Burlat'.

*Means assigned identical letters do not differ significantly at the level of significance $\alpha=0,05$.

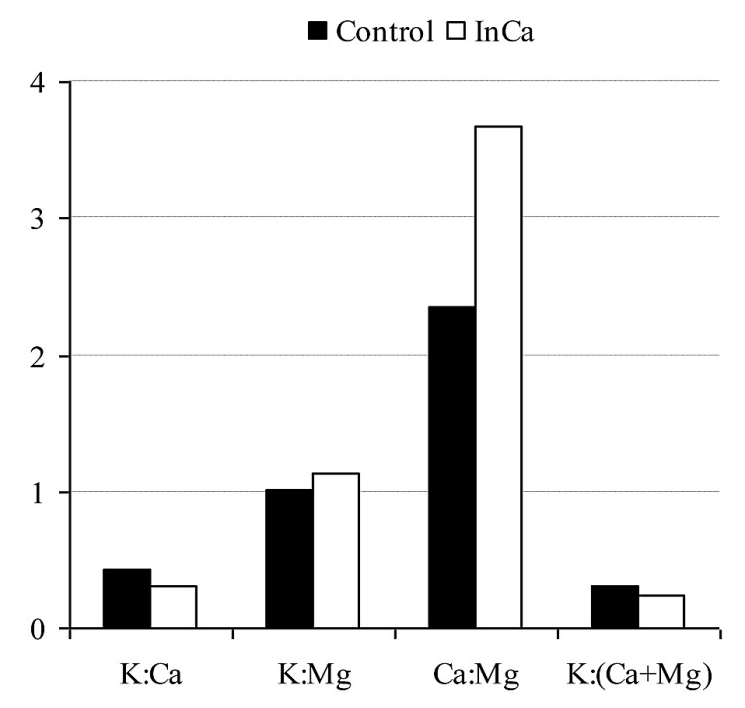

Figure 3. Influence of InCa fertilizer on ion ratio in leaves of sweet cherry cv. 'Burlat'

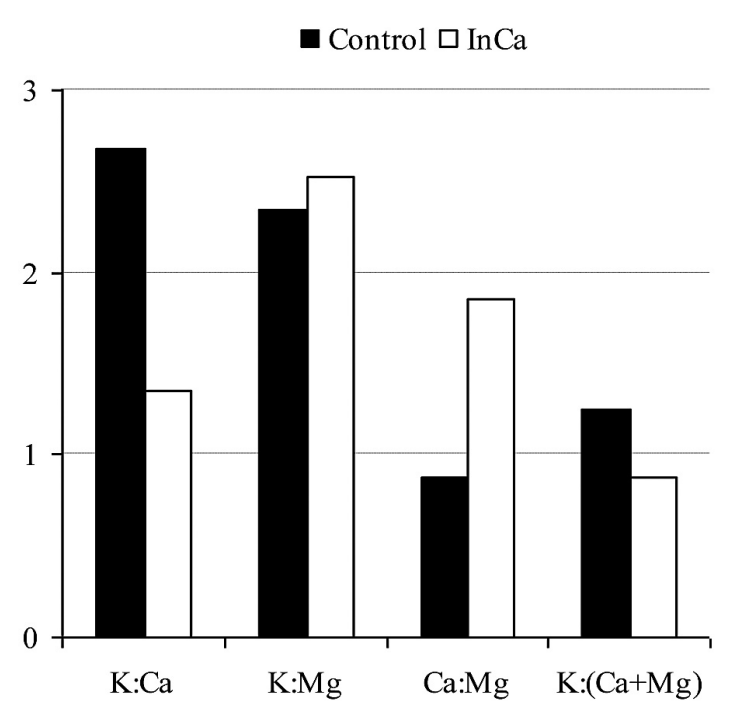

Figure 4. Influence of InCa fertilizer on ion ratio in fruit of sweet cherry cv. 'Burlat' 
Table 2. Influence of InCa fertilizer on content of microelements, lead and cadmium in leaves and fruit of sweet cherry cv. 'Burlat'

\begin{tabular}{|c|c|c|c|c|c|c|}
\hline \multirow{2}{*}{ Specification } & $\mathrm{Mn}$ & $\mathrm{Zn}$ & $\mathrm{Cu}$ & $\mathrm{Ni}$ & $\mathrm{Pb}$ & $\mathrm{Cd}$ \\
\hline & \multicolumn{6}{|c|}{$\mathrm{mg} \cdot \mathrm{kg}^{-1}$ dry matter } \\
\hline \multicolumn{7}{|c|}{ Leaves } \\
\hline Control & $4,34 \mathrm{a}$ & 14,9 a & $7,54 \mathrm{~b}$ & $1,88 \mathrm{~b}$ & $2,49 b$ & $0,02 \mathrm{~b}$ \\
\hline $\operatorname{lnCa}$ & $6,24 \mathrm{~b}$ & 14,9 a & $6,50 \mathrm{a}$ & $1,75 \mathrm{a}$ & $2,00 \mathrm{a}$ & $0,01 \mathrm{a}$ \\
\hline \multicolumn{7}{|c|}{ Fruit } \\
\hline Control & 2,36 a & 2,73 a & $4,26 \mathrm{a}$ & 2,16 a & $1,29 a$ & $0,02 \mathrm{~b}$ \\
\hline InCa & $2,56 \mathrm{a}$ & $2,94 \mathrm{a}$ & $4,45 \mathrm{a}$ & $2,21 \mathrm{a}$ & 1,38 a & $0,01 \mathrm{a}$ \\
\hline
\end{tabular}

* Means assigned identical letters do not differ significantly at the level of significance $\alpha=0,05$.

'Sunburst' cultivar [Jiménez et al. 2004]. In our experiment, the content of cadmium in the leaves and fruits was decreased following the fertilization (Table 2). Heavy metal content in the fruits of the investigated cultivar did not exceed the acceptable levels, neither in control, nor in the supplemented plants [Dz. U. 2003, No 37, item 326].

\section{CONCLUSIONS}

The use of InCa fertilizer improved the dry matter and calcium content and reduced potassium, magnesium and cadmium level in the leaves and fruits of sweet cherry. The fertilizer facilitated narrowing of $\mathrm{K}: \mathrm{Ca}$ and $\mathrm{K}:(\mathrm{Ca}+\mathrm{Mg})$ ratio and extending of $\mathrm{K}: \mathrm{Mg}$, and especially $\mathrm{Ca}: \mathrm{Mg}$ ratio in both leaves and fruits. Foliar supplementation with the investigated preparation resulted in an increase in nitrogen and manganese content, and a drop in phosphorus, copper, nickel and lead concentration in the leaves of the studied sweet cherry cultivar. The fertilizer did not affect the level of nitrogen, nitrates, phosphorus, manganese, copper, nickel and lead in the fruits and sulfur and zinc in the fruits and leaves.

\section{REFERENCES}

1. Andziak J., Tomala K., Sadowski A., Dziuban R. 2004. Stan odżywienia składnikami mineralnymi na zdolność przechowalnicza jabłek 'Šampion' w zależności od podkładki. Acta Sci. Pol., Hortum Cultus 3(2), 179-187.

2. Arysta LifeScience, 2013. Information materials, 9 p.

3. Bieniek A, Kawecki Z., Kopytowski J., Zielenkiewicz J. 2011. Yielding and fruit quality of Lithuanian sweet cherry cultivars grown under the climatic and soil conditions of Warmia. Folia Hort. 23/2, 101-106.

4. Chełpiński P., Lewandowski J., Gembara J., Mikiciuk G. 2007. Wpływ stosowania preparatów
Wapnowit i Calcinit na pękanie owoców czereśni odmiany Burlat. Rocz. AR Poznań CCCLXXXIII, Ogrodn., 41, 291-296.

5. Dziennik Ustaw. 2003. No 37, pos 326.

6. Fernandez R.T., Flore J.A. 1998. Intermittent aplication of $\mathrm{CaCl}_{2}$ to control rain cracking of sweet cherry. Acta Hort., 468, 683-689.

7. Jiménez S., Garin A., Gogorcena Y., Betrán J.A., Moreno M.A. 2004. Flower and foliar analysis for prognosis of sweet cherry nutrition, influence of different rootstocks. J. of Plant Nut., 27(4), 701-712.

8. Khalifa R. Kh. M., Hafez O., M., Abd-El-Khair H. 2009. Influence of foliar spraying with boron and calcium on productivity, fruit quality, nutritional status and controllin of blossom end rot disease of Anna apple trees. World J. of Agricul. Sciences 5(2), 237-249.

9. Lanauskas J., Kviklienė N., Uselis N., Kviklys D., Buskienė L., Mažeika R., Staugaitis G. 2012. The effect of calcium foliar fertilizers on cv. Ligol apples. Plant Soil Environ., 58, (10), 465-470.

10. Meszka B. (red.), Buler Z., Broniarek-Niemiec A., Doruchowski G., Głowacka A., Godyń A., Hołownicki R., Lisek J., Łabanowska B.H., Maciesiak A., Morgaś H., Płuciennik Z., Rozpara E., Sekrecka M., Sobiczewski P., Treder W., Warabieda W., Wójcik P. 2013. Metodyka integrowanej ochrony czereśni dla doradców. Instytut Ogrodnictwa, Skierniewice, 58 p.

11. Neilsen G., Kappel F. 1996. 'Bing' sweet cherry leaf nutrition is affected by rootstock. HortScience 31(7), 1169-1172.

12. Sitarek M., Grzyb Z.S. 1999. Wstępne wyniki wpływu opryskiwania drzew preparatami Seniphos i Stopit na ograniczenie stopnia spękania owoców czereśni. Zesz. Nauk. AR Krak., 351, 297-300.

13. Tomala K., Soska A. 2004. Effects of calcium and/ or phosphorus sprays with different commercial preparations on quality and storability of Šampion apples. Hort. Sci. (Prague), 31(1), 12-16.

14. Wójcik P. 2004. Uptake of mineral nutrients from foliar fertilization (Review). J. Fruit Ornam. Plant Res. Special ed. 12, 201-218. 